Acta Regionalia et Environmentalica 2

Nitra, Slovaca Universitas Agriculturae Nitriae, 2018, pp. 38-42

\title{
THE DEVELOPMENT OF CHOSEN SOCIAL AND ECONOMIC INDICATORS IN RURAL AREAS OF THE SLOVAK REPUBLIC
}

\author{
Marián KOVÁČIK*, Eva ŽUFFOVÁ \\ Slovak University of Agriculture in Nitra, Slovak Republic
}

\begin{abstract}
The focus of the following article was to study development of certain social and economic indicators in Slovakia. We focused this paper on two types of regions in Slovakia, urban and rural. For this purpose we decided to measure the development of inhabitants in rural and urban areas as well as median age of the population. We also partially focused on the sector of agriculture since it used to play an important role in rural areas as a key employer. We found that there is a trend of moving people from urban to rural areas and that agriculture is losing its key role because of decreasing employment trend. This can be caused by low attractiveness of this sector and low income which, nowadays, plays an important role in finding a job.
\end{abstract}

Keywords: rural areas, agriculture, employment in agriculture, rural women

Nowadays, approximately half of the land in the EU is used for agricultural purposes. In 2013, there were 10.8 million farms across the EU utilizing 174.4 million hectares of land which represented approximately $40 \%$ of the total land fund. The average size of agricultural holding in the EU was 16.1 hectares (EC, 2015). Due to past reforms of CAP, the methods of utilizing the land are more environmental friendly with positive impact on rural areas. Approximately half of the EU population lives in rural areas. More than half of the EU land fund can be found in regions classified as predominantly rural (Eurostat, 2012). The OECD has defined predominantly rural region as having more than $50 \%$ of the population living in rural communities with population density over 150 persons per square kilometre (Beshiri and Bollman 2001). There are some differences between rural areas. In general, rural settlements near towns can be characterized as dynamic and stable, whereas settlements farther from town can be characterized with declining overall development as turbulent (Niittykangas, 2006). Agriculture sector plays different role in European countries, e.g., agriculture in Central and Eastern European countries is a much more important component of the economy than in industrialized countries. It traditionally accounted for 15-20\% of GDP and total employment, compared to only $2-3 \%$ in the rest of the EU (Klomp, 2014). Due to economic development in certain regions the farmers try to improve their activities. One of these is taking over the land which was previously used by their competitors. This results in decrease of employment in agriculture and an increase of average farm size (Beckers et al., 2018). Nowadays in Slovakia, there is a similar situation like in the rest of the EU. In 2012, over 50\% of inhabitants lived in predominantly rural areas, almost $40 \%$ lived in intermediate regions and $11.4 \%$ lived in predominantly urban areas.
When considering the area, 59\% of the area belongs to predominantly rural areas, almost $37 \%$ consisted of intermediate regions and $4.2 \%$ consisted of predominantly urban areas. In total, $95.8 \%$ of regions can be considered rural (PRV, 2014). Agriculture can be considered as the main economic activity in majority of rural areas.

The agricultural sector has been related to production of essential food crops for hundreds of years, being the main source of livelihood for many people. The fundamental role of agriculture in economic development of many countries around the world has long been recognized (Alston and Pardey, 2014). The agricultural activity may also have several other functions beyond its role of producing food and fibre, which has emerged as a key notion in scientific and policy debates regarding the future of agriculture and rural development. Current and future members of community profit from rural areas utilized by farmers (EC, Agriculture, 2014). In 2011, about $42 \%$ of the 26.7 million people working regularly in agriculture in the EU were women and at least one holding out of five (around 29\%) was managed by a woman. Women play a major role in civil society and in economic growth in rural areas all over the world (Franic et al., 2015).

Rural areas can also be defined by Eurostat methodology which is based on two hierarchical levels of territorial units local (municipal) and regional. Municipality, on local LAU 2 level, is considered a settlement with density lower than 150 inhabitants per $\mathrm{km}^{2}$. On regional level, there are three types of regions: predominantly rural regions, where $50 \%$ of inhabitants live in countryside; intermediate regions, where $15-50 \%$ of inhabitants live in countryside and predominantly urban regions where only $15 \%$ of inhabitants live in countryside. In Slovakia, there are 79 districts on LAU 1 level out of which 70 can be considered rural. Predominantly rural 
regions consist of 31 districts and the rest are intermediate regions. There are only two predominantly urban regions, the districts with the two biggest cities in Slovakia, Bratislava, the capital in the western Slovakia, and Košice in eastern Slovakia (Buchta, 2012).

Predominantly rural areas have certain specifics when compared to predominantly urban regions. To the main features belong lower concentration of capital, lower concentration of inhabitants which limits the demand for goods and services. There is also lower education level of inhabitants as well as lower vitality index. In countryside, there is lack of certain localization factors which bring to entrepreneurs agglomeration effects such as level of infrastructure, number and size of entrepreneurs (Fáziková, 2009). Despite the negative features, countryside has been becoming more attractive over the past years, especially countryside near the cities. Since the beginning of 90 's, the rural areas have undergone certain changes such as renewal of local municipalities, public administration reforms and decline of certain economic sectors - agriculture and forestry. The accession of Slovakia into the EU brought regulations in primary production, regional development and tourism. All these changes formed the current state of rural areas (Gajdoš, 2015).

\section{Material and methods}

Rural areas represent a dynamic and constantly changing environment. The main goal of the following paper is to describe chosen social and economic indicators in rural areas through analysis of basic data. Our aim is to find new trends in rural areas before and after entering the EU. The theoretical base is provided by several authors operating in the field. The data we used can be found on web pages of the Slovak statistical office, Eurostat database and Green reports done by the Research Institute of Agricultural and Food Economics. When drawing data from these databases we found that there are different time series. Some data were found since 1993, some since 1994, 1996 or 2000. Nevertheless, we used this data to describe the development of these indicators in rural areas. The data were later used to calculate the trend and graphically expressed in MS Excel charts. For the purposes of this article we did not focus on a specific regions; we only used basic division to rural and urban regions in the Slovak Republic. When considering employment rate in rural areas, our assumption was based on general knowledge that in rural areas the main employer is the sector of agriculture. For the purposes of this article, we focused on the following indicators:

- demographic development in rural and urban areas in Slovakia,

- changes in median age of inhabitants in rural and urban areas,

- development of unemployment rate in Slovakia and in rural areas,

- development of employment rate in agriculture since the 90 's,

- analysis of average nominal wages in chosen sectors of economy,

- analysis of current situation in agriculture and employment rate.

\section{Results and discussion}

In the past, agriculture significantly participated in economic development of rural areas. Some said it was a key actor in employment in rural areas. The economic structure of countryside was based on traditional rural sectors such as agriculture, forestry and fishery. Nowadays, there is an increasing importance of other sectors which can effectively use local resources, e.g. rural tourism, agro-tourism and traditional craftsmanship. There can also be other sectors, those that increase the quality of life, such as social services (Gajdoš, 2015). Of course, the countryside simply cannot provide advantages compared to concentrated capital in urban areas. On the other hand, countryside can provide effective forms of organisation and cooperation in agriculture, food processing and forestry. Rural areas can provide better base for creating associations among businessmen, municipalities and partnerships which help the development of municipality and tourism (Gajdoš, 2015). There are, and there will be, differences between rural and urban ways of life. The fact is that majority of Slovak inhabitants live in urban areas, but the quality of their life is connected to rural areas, when considering the quality of environment, primary production, active free time in nature, cultural and historical sightseeing. The trend in residency was changing during 1993-2015 period. At the beginning and during the 90 's, there was a tendency of living in urban areas, but later after 2000, there was a shift towards living in rural areas. The causes of moving to cities were different e.g. better job opportunities, education, civic amenities, access to services or the quality of infrastructure.

There were recorded changes at the beginning of the new millennium. We can see an increase of population in rural areas and this trend has continued up to today. The rural areas are especially attractive for young families who are looking for a quiet lifestyle in combination with lower living costs (Dugovič, 2015). Among other advantages of rural areas we can mention higher availability of land and cleaner and healthier environment. The migration to rural areas can be seen in the whole region of Slovakia. The Figure 2 shows us the changes in urban - rural migration by sex. We can see that not only women form a higher share in population, but also both sexes have increasing tendency of living in rural areas.

The trend in this migration is also supported by the changes in median age in urban and rural areas (Figure 3 ). Since 2000, there has been recorded lower median age in rural areas (38 years) than in cities (40). This chart can support the hypothesis that younger people are moving from urban to rural areas. Rural areas have been experiencing a new boom; people leave the comfort of big cities, good infrastructure and advanced services (Dugovič, 2015). The reason for this migration can be the desire for a family house that is often financially unsustainable in cities. A family house is considered to be the best way of living that can be achieved and is connected with the ideas of a happy life (Gajdoš, 2012).

On the other hand, from the overall point of view, the age of population is constantly rising in both rural as well as urban regions indicating population ageing which can lead to several social and economic problems. The increasing 


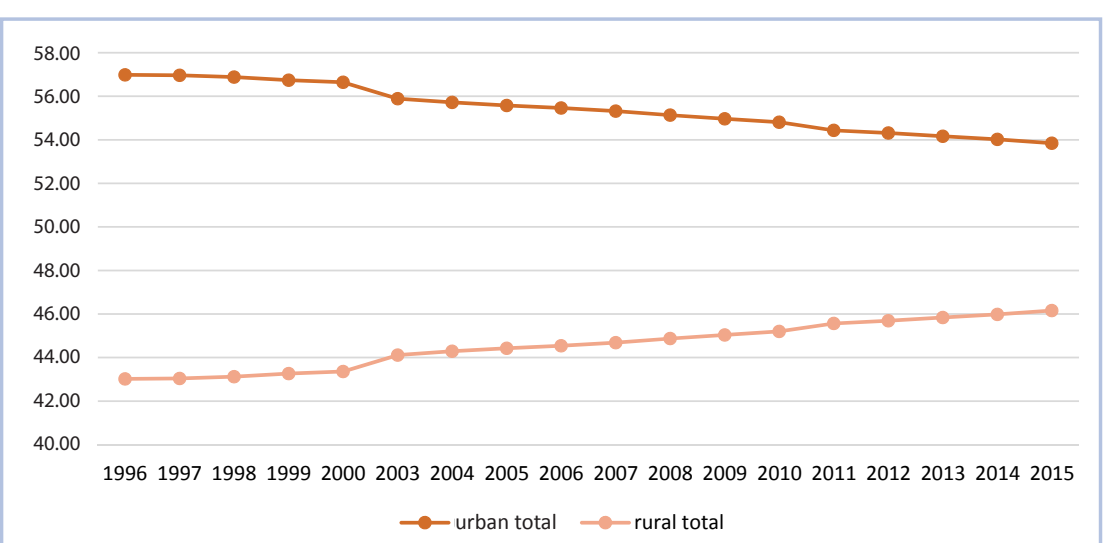

Figure 1 Development of population in urban and rural areas during 1996-2015 period in \%

Source: Statistical Office of the Slovak Republic, 2017

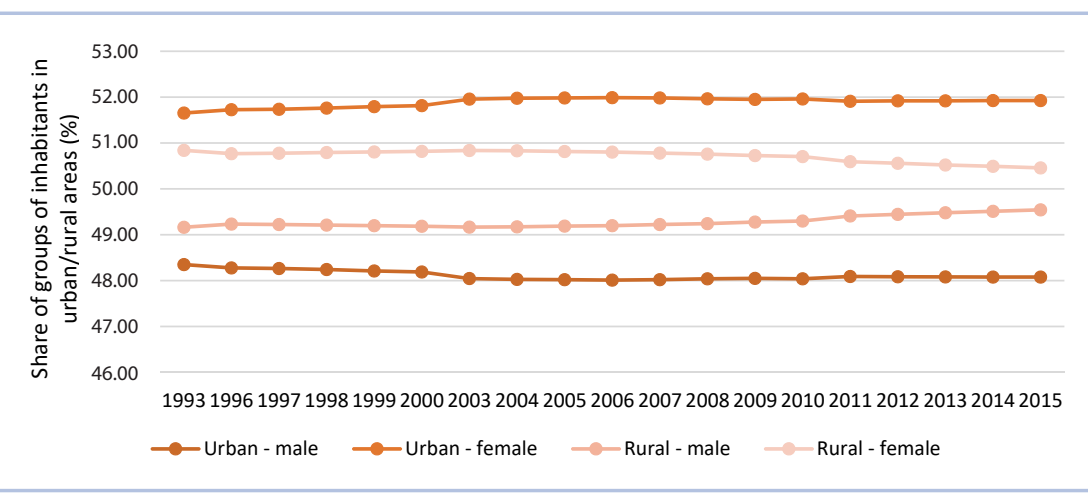

Figure 2 Share of population in urban/rural area by sex during 1993-2015 period in \%

Source: Statistical Office of the Slovak Republic, 2017

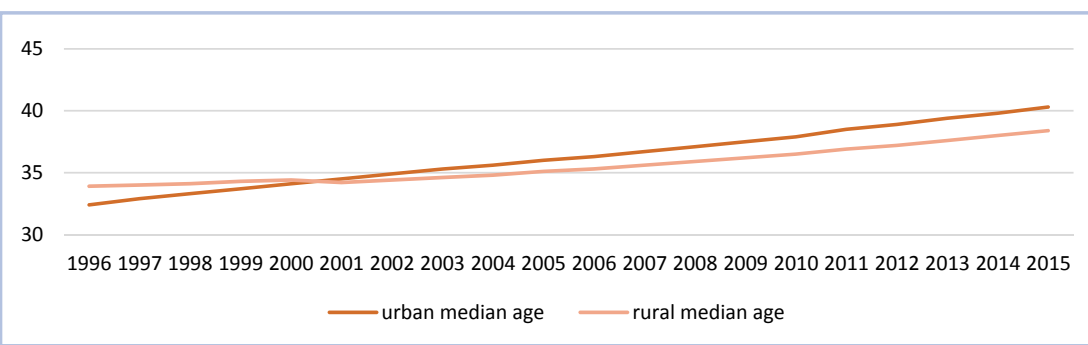

Figure 3 Development of median age in urban and rural areas Source: Statistical Office of the Slovak Republic, 2017

share of seniors in the future will be reflected in every developed economy as well as in the structure of its population consumption (TASR, 2016). Changes in the number, increase, distribution and age structure of population, caused by changes in the reproductive and family behaviour of population will have a serious impact on social development. Impact will affect all areas of societal life, first of all the labour market, social insurance, health care and social services (Vaňo, 2015). permanent economy structure (Stanek et al., 2002). The development of unemployment has been changing in Slovakia since the creation of the Slovak Republic in 1993. The most critical period can be considered from 2000 to 2002. Another critical period showed up after the 2008 economic crisis. In Slovakia, the negative effects started to be observed in the following years of 2009 and 2010. This crisis had a negative effect on GDP growth as a result of decreased foreign demand for Slovak production. Industrial sector was the most affected area as it is considerably dependent on development of world markets. All these negative effects resulted in higher rate of redundancies (Laurová, 2012).

The unemployment rate in rural areas is considerably higher than in urban areas. There are several reasons which explain this situation. One of the most significant reasons is insufficient educational and qualification structure of human resources, low mobility and connection to agriculture (Fáziková, 2005). Although the unemployment rate is decreasing during the studied period, there are still differences between males and females. The unemployment rate of females is higher than in case of males (Fig. 4). Since agriculture is still one of the important sectors in rural areas, the following text will focus on employment in agriculture. When considering the employment in general, the share of agriculture is low, but the ability to create new jobs is higher than in other sectors. This job position in rural areas, unlike in other sectors, does not require high mobility or building the follow-on infrastructure such as housing, transportation, etc. (Buchta, 2015). Generally, in Slovakia, the share of agriculture on employment has a long term decreasing tendency, but when looking at the situation in rural areas, this share is higher than on the national level. Nowadays, agriculture cannot be seen as the main source of employment in rural areas. It is necessary to take into account the difference between permanent and seasonal employees. Among the employees, there is an ageing trend. The share of employees younger than 35 years has been decreasing. On the other hand, there was an increase of older employees who are over 60 years old. These are mainly small farms 
holders of up to 5 ha (Kováčik et al., 2016). Various factors contributed to redundancy in agriculture. Utilizing the land has become more advanced, new technologies have been supplying human resources, and this trend is increasing. Conventional farming is capable of larger production using less human resources and time. Decrease of import duties and "removing" the borders had resulted in larger and cheaper variety of products (especially

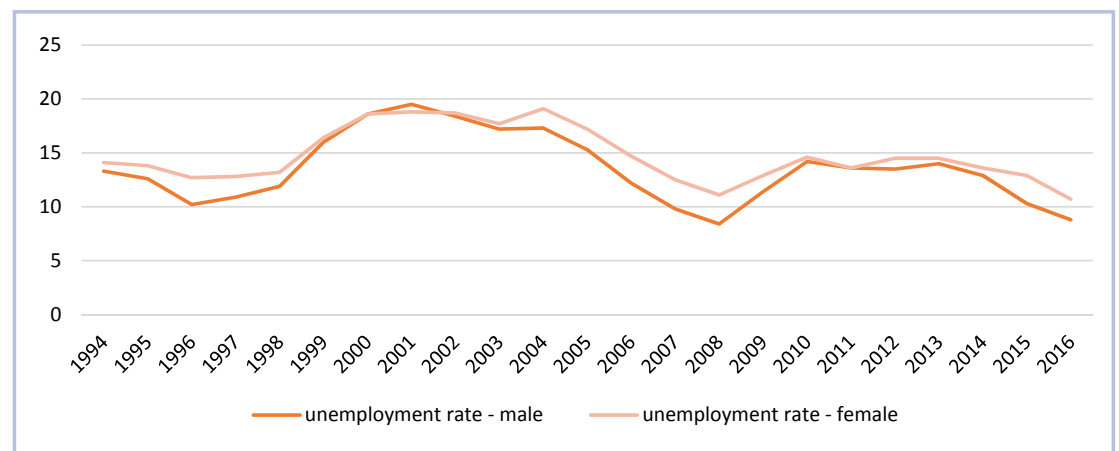

Figure 4 Development of unemployment rate in Slovakia in \% Source: Statistical Office of the Slovak Republic, 2017

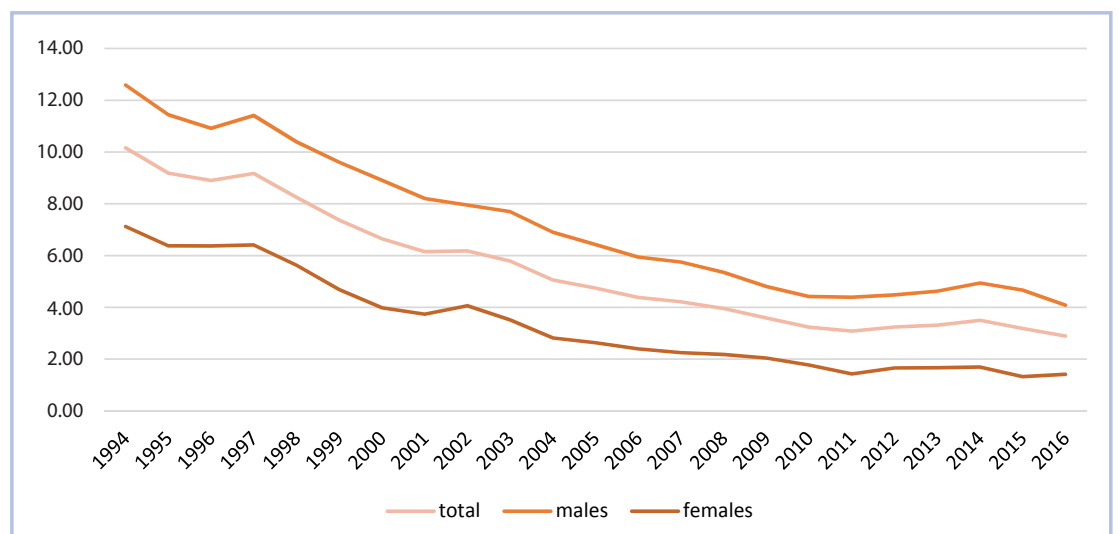

Figure 5 Development of employment in the sector of agriculture in Slovakia 1994-2016 in \%

Source: Statistical Office of the Slovak Republic, 2017; RIAFE 2017

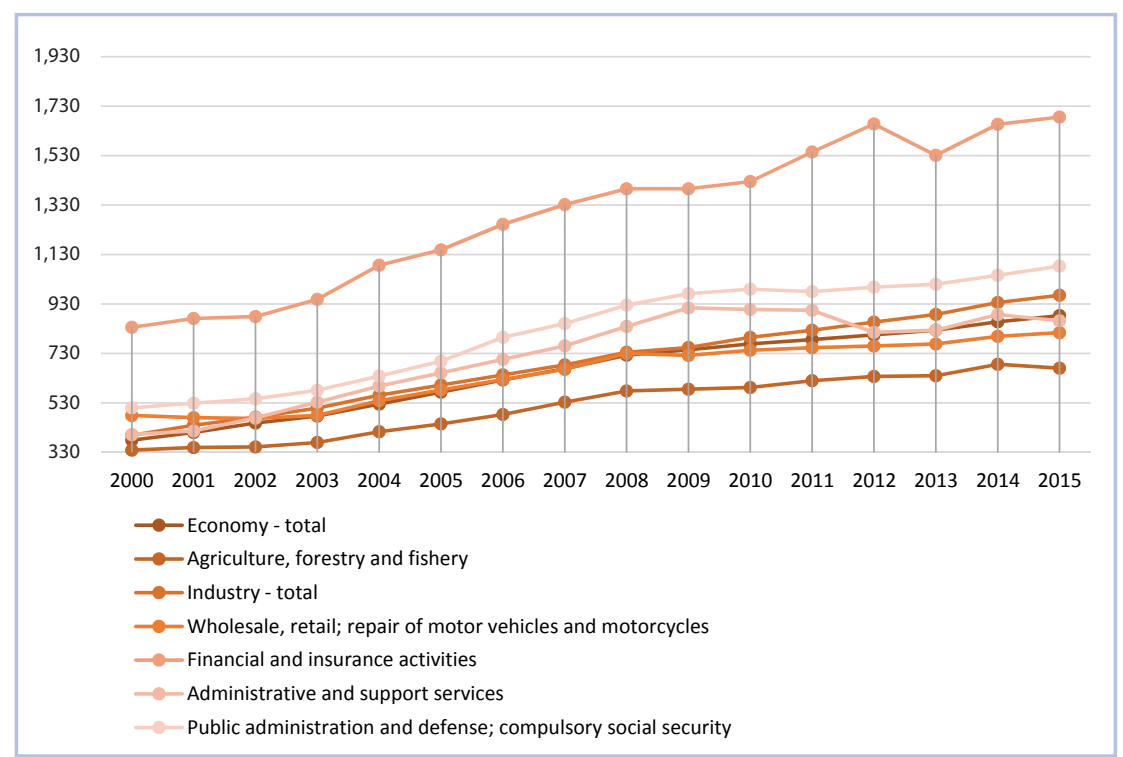

Figure 6 Average monthly income in absolute values in $€$ Source: Statistical Office of the Slovak Republic, 2017

fruits and vegetables) interesting for consumers. This can be seen as another factor which, in the end, helped to decrease the job supply in agricultural sector. The farmers had to change their production structure in order to become more competitive to foreign products.

In the end, we need to take into account that employment in agriculture has become less attractive for younger people and working in rural areas is not in accordance with their perception of life. But it is necessary to state that this phenomenon can be seen in all EU member countries. In 2012, 10.3 million of people were employed in agriculture in EU-28. In 2014, this number decreased by over 600,000 people. Based on Eurostat (2016), the highest share of agriculture on employment (over 10\%) can be seen in countries like Romania (16.6\%), Greece (12.9\%), Poland (12.2\%), Croatia (12.1\%), Lithuania (11.4\%) and Hungary (11.3\%).

Since the beginning of the 1990's, a constant decrease of employment in agriculture has been observed. Of all the people employed in agriculture, women constituted $1 / 4$. From long-term point of view, this share has not been changing. In 2014, there was a slight increase of this share by $1.4 \%$ compared to 2013. This slight increase has resulted from the activities realized under the Rural Development Programme of the Slovak Republic 2007-2013. This programme contained measures aimed at job creation in the sector of agriculture. Changes can also be observed in the structure of employees. In recent period, there is an increase of administrative workers and a decrease of "traditional" manual workers.

Changes can also be observed in the structure of employees. The age of the employees is also rising due to low interest of younger generation (Riafe, 2016). In the past years, there has been an increase of administrative workers and a decrease of "traditional" manual workers. On the other hand, employment in agriculture does not seem attractive when considering the level of income. On the figure 6 we can see differences in average monthly income in selected branches of economy. We can see that income in agriculture is the lowest and also with the lowest development. The highest income was in the sector of financial and insurance activities. 
Labour assessment in agriculture is different when considering the sex of employees. Qualified estimates show us that average salaries of women are $20 \%$ lower compared to men (Buchta, 2008).

\section{Conclusion}

Rural areas are characterized by their specifics which have undergone several changes during the previous years. Not only the rural areas are changing, but also the human perception of rurality is changing. During the 1990-2015 period, we saw several changes in selected indicators. Firstly, there are changes in living preferences towards the rural areas. After the year 2000 there can be seen significant migration from urban to rural areas. Especially, the "middle generation" is looking for living in a calm rural area.

The rural areas are naturally connected to agriculture as its main employer. Recently there have begun changes towards non-agricultural services and therefore this sector has undergone several changes in the past years. The number of people working in agriculture has been constantly decreasing. Among the causes of this development we can include the innovation and modernisation of agricultural sector and the low job attractiveness due to the level of income. Low salary and, usually, the hard-physical work repel the possible young labour force.

These events contributed to changes, shaping rural areas. Despite the increase of inhabitants in rural areas, the employment rate remains lower. Most of the newcomers continue to work in urban areas and use the rural areas only for living without further economic impact. The results of this paper can be used for further study of rural areas in Slovakia as well as a comparison with other EU member states; particularly with "2004" new member states in comparison to EU-15 states in order to see the similarities or differences in rural development in the EU.

\section{References}

ALSTON, J. M. - PARDEY, P.G. 2014. Agriculture in the global economy. In J. Econ., Perspect, 2014, no. 28, pp. 121-146. [on-line] Available on: http://www.sciencedirect.com/science/article/pii/ S0264837716304331

BECKERS, V. et al. 2018. Modelling Farm Growth and Its Impact on Agricultural Land Use: A Country Scale Application of an AgentBased Model. In Land, vol. 7, 2018, no. 3. ISSN 2073-445X

BESHIRI, R. - BOLLMAN, R.D. 2001. Population structure and change in predominantly rural regions, in Rural and Small-Town Canada Analysis. In Bulletin, vol. 2, 2001, no. 2.

BUCHTA, S. 2008. Ženy v polnohospodárstve a na vidieku patria k najzranitel'nejším sociálnym skupinám. [on-line] Available on http://www.etrend.sk/trend-archiv/rok-/cislo-J\%C3\%BAn/zenyv-polnohospodarstve-a-na-vidieku-patria-k-najzranitelnejsimsocialnym-skupinam.html

BUCHTA, S. 2012. Vývojové trendy vidieckych a mestských oblastí Slovenska. In Economics of Agriculture, vol. 12, 2012, no. 4.

BUCHTA, S. 2015. Agrárna zamestnanost' sa vlani prvý raz od roku 1989 zvýšila. In Nové Slovo. 2015. [on-line] Available on http://www.noveslovo.sk/c/ Agrarna_zamestnanost_sa_vlani_prvy_raz_od_roku_1989_zvysila ECONOMICS of Agriculture. vol. 12, 2012, no. 4. [on-line] Available on: www.vuepp.sk/EP2012/4/tah4.php

DUGOVIČ, M. 2015. Väčšie mestá strácajú obyvatel'ov - st'ahujú sa na vidiek a vracajú sa za prácou. [on-line]. Available on: https:// dennikn.sk/332114/vacsie-mesta-stracaju-obyvatelov-stahuju-savidiek-vracaju-sa-za-pracou/

EK, POLNNOHOPOSPODÁRSTVO. 2014. Polnohospodári ako hybná sila vidieka. pp. 9-10. ISBN 978-92-79-41406-0.

EP. 2011. Správa o úlohe žien v polnohospodárstve a vo vidieckych oblastiach. [on-line] Available on: http://www. europarl.europa.eu/sides/getDoc.do?pubRef=-//EP// TEXT+REPORT+A7-2011-0016+0+DOC+XML+V0//SK

EUROSTAT. 2012. Available on: http://epp.eurostat.ec.europa.eu/ cache/ITY_PUBLIC/5-07052010-AP/EN/5-07052010-AP-EN.PDF

EUROSTAT. 2015. Farm structure statistics. Available on: https://ec.europa.eu/eurostat/statistics-explained/index.php/ Farm_structure_statistics

FÁZIKOVÁ, M. 2005. Zmeny v migrácii vidieckeho obyvatel'stva SR $\checkmark$ procese transformácie. In Acta regionalia et environmentalica, vol. 1, 2005, no. 1. pp. 9-11. ISSN 1336-5452,

FÁZIKOVÁ, M. 2009. Pojem vidieka, definícia, typológia prednáška z Rozvoja vidieka. [on-line]. Available on: http://www. fesrr.uniag.sk/sites/default/files/1\%20POJEM\%20VIDIEKA,\%20 DEFIN\%C3\%8DCIA,\%20TYPOL\%C3\%93GIA.pdf

FRANCIS, R. et al. 2015. International Day of Rural Women 2015. Compilation of an in-depth analysis and a study workshop. ISBN 978-92-823-8192-2.

GAJDOŠ, P. 2012. Zmeny $v$ bývani $v$ meste a na vidieku. 2012[on-line]. Available on: http://www.uzemneplany.sk/sutaz/ zmeny-v-byvani-v-meste-a-na-vidieku

GAJDOŠ, P. 2015. Ako sa mení vidiek na Slovensku. Bratislava : Sociologický ústav SAV, 2015. ISBN 978-80-85544-87-9.

KALIŇÁK, M. 2017. Vidiek má svoju cenu. In Obecné noviny. 2017. [on-line]. Available on: http://www.obecne-noviny.sk/clanky/ vidiek-ma-svoju-cenu

KLOMP, J. 2014. The political economy of agricultural liberalization in Central and Eastern Europe: An empirical analysis. In Food Policy, vol. 49, 2014, Part 1, pp. 332-346.

KOVÁČIK, M. - BEŇUŠ, O. - SCHWARCZ, P. - BUMBALOVÁ, M. 2016. Current trend in human resources in the sector of agriculture in the Slovak Republic. In RELIK, 2016. Praha : Vysoká škola zemědelská, 2016, pp. 285-292. ISBN 978-80-245-2166-4.

LAUROVÁ, M. 2012. Dopady hospodárskej krízy na vývoj ekonomiky v SR. In Podnikanie v Európskej únii. Obchodné právo EÚ II : zborník príspevkov z medzinárodnej vedeckej konferencie. Nitra : SPU, 2012, pp. 76-79. ISBN 978-80-552-0819-0.

NIITTYKANGAS, H. 2006. Enterprise development in different rural areas of Finland. In Journal Entrepreneurship \& Regional Development. [on-line]. Available on: http://dx.doi. org/10.1080/08985629600000015

PROGRAM ROZVOJA VIDIEKA SR 2014-2020. [on-line]. Available on: www.mpsr.sk/download.php?fID $=8223$

SO SR, Demographic and social statistics. 2017. [on-line]. Available at: <http://datacube.statistics.sk/\#!/lang/en

STANEK, V. et al. 2002. Sociálna politika. Bratislava : Sprint, 2002. 474 p. ISBN 80-8884-92-X.

STRATEGY 2020. 2010. A strategy for smart, sustainable and inclusive growth. Brussels: European Commission. [on-line]. Available on: http//ec.europa.eu/europe 2020/

TASR. 2016. Starnutie populácie zmení aj charakter spotrebitel'ov. [on-line]. Available on: https://www.teraz.sk/ekonomika/analyticivplyvom-starnutia-populacie/220275-clanok.html

UHNÁK, J. 1998. Nezamestnanost' je produkt pretechnizovanej spoločnosti. In Trend, 1998, no. 34, p. 22A. ISSN 1335-0684.

VAŇO, B. 2015. Súčasný a očakávaný populačný vývoj na Slovensku a jeho spoločenské a ekonomické dopady. In Prognostické práce, vol. 7, 2015, no. 3. [on-line]. Available on: www.prog.sav.sk/sites/ default/files/2018-03/Vano_PP3_clanok_doplneny_c_4.pdf 